\title{
PENGARUH DISIPLIN KERJA DAN PELATIHAN KERJA TERHADAP KINERJA KARYAWAN
}

\author{
(Studi kasus pada PT Ardena Artha Mulia bagian produksi)
}

\author{
Sri Lestari, Dilla Afifah \\ Program Studi Manajemen Universitas Islam As-Syafi'iyah \\ srilestari.feb@uia.ac.id; dillaafifah123@gmail.com
}

\begin{abstract}
This study aims to determine the effect of work and training on employee performance (a case study at PT Ardena Artha Mulia in the production section). The number of samples is 50 employees, all of which are respondents in this study. The data technique used a questionnaire, the data were analyzed using the SPSS version 25 program. The analysis performed was regression and regression analysis, coefficient of determination, f test, and t test. Based on the results of hypothesis testing partially work discipline has no effect on employee performance with a significance level of 0,108 $>0,05$ and $t_{\text {count }} 1,639<1,678$. Partially job training has a positive and significant effect on employee performance with a significance level of 0,000 $<0,05$ and $t_{\text {count }} 5,112>1,678$. The coefficient of determination (R2) for the work discipline variable is 0,317 , meaning that it provides a contribution of the influence of work influence on employee performance by $31,7 \%$ and the remaining $68,3 \%$ from other factors such as: compensation, motivation, leadership style, and others. The coefficient of determination (R2) for the job training variable is 0,536, meaning that it provides a contribution of the effect of training on employee performance by $53,6 \%$ and the remaining $46,4 \%$ is influenced by other factors such as: work
\end{abstract}

\section{Keywords: Work Discipline, Work Training, Employee Performance.}

\begin{abstract}
Abstrak
Penelitian ini bertujuan untuk mengetahui pengaruh disiplin kerja dan pelatihan kerja terhadap kinerja karyawan (studi kasus pada PT Ardena Artha Mulia bagian produksi). Jumlah sampel adalah 50 karyawan, yang mana semuanya menjadi responden dalam penelitian ini. Teknik pengumpulan data menggunakan kuesioner, data dianalisis dengan menggunakan program SPSS versi 25. Analisis yang dilakukan adalah analisis regresi dan korelasi, koefisien determinasi, uji f, dan uji t. Berdasarkan hasil pengujian hipotesis secara parsial disiplin kerja tidak berpengaruh terhadap kinerja karyawan dengan tingkat signifikansi sebesar 0,108 >0,05 dan $t_{\text {hitung }} 1,639<1,678$. Secara parsial pelatihan kerja berpengaruh positif dan signifikan terhadap kinerja karyawan dengan tingkat signifikansi sebesar 0,000 $<0,05$ dan thitung 5,112 > 1,678. Koefisien determinasi (R2) untuk variabel disiplin kerja sebesar 0,317 artinya presentase sumbangan pengaruh disiplin kerja terhadap kinerja karyawan sebesar $31,7 \%$ dan sisanya $68,3 \%$ dipengaruhi oleh faktor lain seperti: kompensasi, motivasi, gaya kepemimpinan, dan lain-lain. Koefisien determinasi (R2) untuk variabel pelatihan kerja sebesar 0,536 artinya presentase sumbangan pengaruh pelatihan kerja terhadap kinerja karyawan sebesar 53,6\% dan sisanya $46,4 \%$ dipengaruhi oleh faktor lain seperti: lingkungan kerja, job descroption, pendidikan, dan lain-lain.
\end{abstract}

Kata kunci : Disiplin Kerja, Pelatihan Kerja, Kinerja Karyawan. 


\section{PENDAHULUAN}

\subsection{Latar Belakang}

Sumber daya manusia memiliki peran penting bagi perusahaan, karena sumber daya manusia merupakan kombinasi antara tenaga, fisik, ide, bakat, pengetahuan, kreatifitas, dan keterampilan yang dibutuhkan untuk menggerakkan perusahaan. Sumber daya manusia merupakan modal dan kekayaan terpenting dari setiap kegiatan manusia (Mamik, 2016), yang berarti perusahaan tidak akan berfungsi dengan baik tanpa sumber daya manusia (SDM). Karyawan memiliki andil sebagai perencana, pelaksana dan pengendali yang selalu berperan aktif dalam mewujudkan tujuan perusahaan. Keberhasilan suatu perusahaan sangat dipengaruhi oleh kinerja karyawannya. Karena kinerja

seorang karyawan merupakan awal yang sangat penting bagi terciptanya kemajuan perusahaan.

Dalam kaitannya kinerja karyawan pada suatu perusahaan, dibutuhkan SDM yang memiliki disiplin dan standar/kemampuan kerja yang baik, sehingga dapat mempengaruhi hasil kerja sesuai standar kualitas perusahaan. Kinerja merupakan hasil yang produksi oleh fungsi pekerjaan tertentu atau kegiatan-kegiatan pada pekerjaan tertentu pada periode waktu tertentu (Priansa,2019). Hasil kerja tersebut merupakan hasil dari kemampuan, keahlian, dan keinginan yang dicapai. Akan tetapi kinerja sebenarnya mempunyai arti yang lebih luas, bukan hanya hasil kerja, tetapi termasuk bagaimana proses pekerjaan itu berlangsung.

Tabel 1.1

Laporan Hasil produksi periode 2017-2019

\begin{tabular}{|c|c|c|c|c|c|c|}
\hline \multirow[t]{2}{*}{ Produk } & \multicolumn{2}{|c|}{2017} & \multicolumn{2}{|c|}{2018} & \multicolumn{2}{|c|}{2019} \\
\hline & Target & Realisasi & Target & Realisasi & Target & Realisasi \\
\hline Chicken siomay & 10.000 & 9.125 & 12.000 & 10.850 & 15.000 & 13.300 \\
\hline Chili fish papper & 10.000 & 9.490 & 12.000 & 11.225 & 15.000 & 14.015 \\
\hline Fish crab roll & 10.000 & 8.700 & 12.000 & 10.910 & 15.000 & 13.100 \\
\hline Salmon ball & 10.000 & 9.200 & 12.000 & 10.200 & 15.000 & 12.150 \\
\hline Octopus ball & 10.000 & 8.230 & 12.000 & 9.830 & 15.000 & 11.080 \\
\hline Shrimp ball & 10.000 & 8.900 & 12.000 & 10.100 & 15.000 & 14.250 \\
\hline Kaki naga & 10.000 & 9.100 & 12.000 & 11.300 & 15.000 & 13.900 \\
\hline Squid ball & 10.000 & 8.135 & 12.000 & 10.200 & 15.000 & 12.100 \\
\hline Donut nugget & 10.000 & 9.600 & 12.000 & 11.600 & 15.000 & 13.200 \\
\hline Fish scallop & 10.000 & 8.950 & 12.000 & 10.250 & 15.000 & 11.150 \\
\hline Total & 100.000 & 89.430 & 120.000 & 106.465 & 150.000 & 128.245 \\
\hline$\%$ Pencapaian & & $89,43 \%$ & & $\mathbf{8 8 , 7 2 \%}$ & & $85,49 \%$ \\
\hline Growth & & & & $0,71 \%$ & & $3,23 \%$ \\
\hline
\end{tabular}

Sumber : HRD PT Ardena Artha Mulia (data diolah)

Setelah penulis melakukan wawancara dengan kepala bagian produksi PT Ardena Artha Mulia mengenai fenomena yang terjadi pada perusahaan, kepala bagian produksi mengatakan bahwa adanya penurunan hasil produksi pada PT Ardena Artha Mulia dalam 3 tahun terakhir. Hal ini dapat dilihat pada tabel 1.1 yang menjelaskan bahwa pencapaian hasil produksi PT Ardena Artha Mulia dalam kurun waktu 3 tahun terakhir periode 2017-2019, masih dibawah harapan target produksi perusahaan. Hal ini disampaikan bahwa kontribusi terbesar adalah faktor manusia yaitu kinerja karyawan.

Apabila hal ini terus berlanjut dan tidak ada solusinya, maka dikhawatirkan akan 
berdampak pada kinerja organisasi secara keseluruhan, dapat diketahui bahwa masih terlihat kesenjangan yang tidak sesuai dengan idealisme karyawan yang memiliki kinerja yang

tinggi, yang seharusnya melaksanakan tugas sesuai dengan tanggung jawab yang diberikan padanya.

Berdasarkan hasil wawancara dengan kepala bagian produksi PT Ardena Artha Mulia menyatakan bahwa

penurunan hasil produksi ini dipengaruhi oleh beberapa faktor diantaranya yaitu, terdapat beberapa karyawan yang menunjukkan kinerja kurang maksimal, seperti datang kekantor tidak sesuai dengan jam yang telah ditentukan perusahaan (terlambat), lalu banyaknya karyawan tidak hadir tanpa keterangan (alpa). Kemudian dari hasil pengamatan saya dilapangan masih banyak karyawan yang saling mengobrol di jam kerja yang mana hal ini dapat berpengaruh terhadap hasil produksi dan tentunya dapat mengulur waktu kerja. Maka terlihat bahwa kedisiplinan yang ditunjukan oleh para karyawan menambah masalah yang harus dihadapi oleh PT Ardena Artha Mulia. Setiap perusahaan perlu memelihara disiplin karyawannya, karena tanpa disiplin yang baik maka operasi perusahaan akan cenderung mengalami kekacauan yang berakibat pada kerugian materi maupun kemunduran kinerja perusahaan (Astuti, 2018).

Berikut ini adalah daftar absensi karyawan bagian produksi PT Ardena Artha Mulia (periode 2018,2019) :

Tabel 1.2

Absensi Karyawan pada bagian Produksi

\begin{tabular}{|c|c|c|c|c|c|c|c|c|c|c|c|c|c|c|}
\hline \multirow[t]{2}{*}{ Bulan } & \multicolumn{7}{|c|}{2018} & \multicolumn{7}{|c|}{2019} \\
\hline & $\mathrm{A}$ & $\mathrm{S}$ & $\mathrm{T}$ & I & $\begin{array}{c}\text { Total } \\
\text { Absensi }\end{array}$ & $\sum$ Karyawan & $\%$ & $\mathrm{~A}$ & $S$ & $\mathrm{~T}$ & I & $\begin{array}{c}\text { Total } \\
\text { Absensi }\end{array}$ & karyawan & $\%$ \\
\hline Januari & 10 & 2 & 1 & 2 & 15 & 50 & $30 \%$ & 13 & 1 & 4 & 0 & 18 & 50 & $36 \%$ \\
\hline Februari & 8 & 3 & 4 & 0 & 15 & 50 & $30 \%$ & 7 & 2 & 6 & 1 & 16 & 50 & $32 \%$ \\
\hline Maret & 9 & 0 & 2 & 1 & 12 & 50 & $24 \%$ & 11 & 5 & 3 & 0 & 19 & 49 & $39 \%$ \\
\hline April & 8 & 1 & 3 & 0 & 12 & 50 & $24 \%$ & 9 & 2 & 5 & 0 & 16 & 50 & $30 \%$ \\
\hline Mei & 12 & 0 & 6 & 2 & 18 & 49 & $37 \%$ & 10 & 3 & 2 & 2 & 17 & 50 & $34 \%$ \\
\hline Juni & 17 & 2 & 4 & 3 & 26 & 50 & $52 \%$ & 18 & 2 & 3 & 4 & 27 & 50 & $54 \%$ \\
\hline Juli & 11 & 0 & 3 & 0 & 14 & 50 & $28 \%$ & 12 & 1 & 2 & 0 & 15 & 48 & $31 \%$ \\
\hline Agustus & 9 & 1 & 2 & 1 & 13 & 50 & $26 \%$ & 15 & 4 & 2 & 0 & 21 & 48 & $44 \%$ \\
\hline September & 11 & 3 & 5 & 0 & 19 & 49 & $39 \%$ & 9 & 2 & 7 & 0 & 18 & 50 & $36 \%$ \\
\hline Oktober & 8 & 2 & 3 & 2 & 15 & 47 & $32 \%$ & 10 & 1 & 5 & 0 & 16 & 50 & $32 \%$ \\
\hline November & 12 & 3 & 2 & 0 & 17 & 50 & $34 \%$ & 11 & 2 & 4 & 1 & 18 & 50 & $36 \%$ \\
\hline Desember & 10 & 0 & 6 & 3 & 19 & 50 & $38 \%$ & 8 & 2 & 4 & 2 & 16 & 50 & $32 \%$ \\
\hline $\begin{array}{l}\text { Rata-rata } \\
\text { Persentase }\end{array}$ & & & & & & & $32,8 \%$ & & & & & & & $36,3 \%$ \\
\hline
\end{tabular}

Sumber : HRD PT Ardena Artha Mulia (data diolah)

Keterangan

$\mathrm{A}=$ Alpa

$\mathrm{S}=$ Sakit

$\mathrm{T}=$

Terlamb

at $\mathrm{I}=$

Izin

Dari data absensi diatas dapat dilihat bahwa adanya peningkatan ketidakdisiplinan di tahun 2018 sampai 2019. Rata-rata absensi karyawan PT Ardena Artha Mulia pada tahun 2018 sebesar 32,8\%, kemudian pada tahun 2019 sebesar $36,3 \%$. Hal ini yang menjadi masalah karena karyawan pada bagian produksi sering 
tidak hadir sehingga menghambat proses produksi, dimana mesin-mesin yang seharusnya terpakai semua untuk memproduksi barang menjadi tidak bisa digunakan secara maksimal karena banyaknya karyawan yang tidak hadir, sehingga target produksi yang ditetapkan oleh perusahaan tidak tercapai. Perusahaan memberikan sanksi terhadap karyawan yang sering alpa lebih dari 15 kali dalam setahun dengan sanksi pemberhentian kerja. Hal ini bertujuan agar karyawan dapat disiplin dan juga mau mematuhi peraturan-peraturan yang berlaku didalam perusahaan.

Dilihat dari fenomena-fenomena yang ada pelatihan kerja menjadi salah satu yang dibutuhkan dalam proses memajukan perusahaan. Pelatihan yang dimaksud yaitu tentang perubahan, transformasi dan pembelajaran. Pelatihan adalah proses yang dirancang untuk membantu pegawai mempelajari keterampilan, pengetahuan, dan sikap baru. Akibatnya karyawan tersebut akan membuat perubahan atau transformasi untuk meningkatkan kinerjanya. Perbaikan ini memastikan bahwa karyawan dan organisasi mampu melakukan hal-hal yang lebih baik, lebih cepat, lebih mudah, dengan kualitas yang lebih tinggi dan laba atas investasi yang lebih baik (Priansa, 2019). Selain itu, berdasarkan hasil wawancara dengan kepala bagian produksi PT Ardena Artha Mulia bagian produksi, peneliti mendapatkan informasi bahwa pelatihan kerja menjadi salah satu faktor yang mempengaruhi kinerja karyawan. Pelatihan yang dilakukan oleh PT Ardena Artha Mulia kepada karyawan bertujuan untuk menaikkan kinerja yang dimiliki oleh karyawan khususnya pada bagian produksi. Karena jika karyawan mengikuti pelatihan akan berdampak pada peningkatan kinerja sehingga laba pada perusahaan akan meningkat. Adanya pelatihan yang diberikan itu sendiri berdasarkan pekerjaan masing-masing karyawan, agar adanya peningkatan kemampuan, pengetahuan dan skill karyawan pada bidangnya sehingga target yang ditetapkan dapat tercapai.

Dari informasi yang penulis dapatkan dari kepala bagian produksi pelatihanpelatihan yang sudah di lakukan oleh perusahaan berupa pemberian materi-materi secara teori yang berguna untuk menambah wawasan karyawan agar lebih luas dan juga didukung pelatihan secara praktek sehingga karyawan dapat mempraktekkannya secara langsung dan dibawah pengawasan instrukrur/pelatih profesional. Pelatihan secara praktek ini penting untuk karyawan agar dapat menyelesaikan tugas-tugas atau beban kerja yang diberikan agar lebih cepat selesai dan efisien waktu, untuk memperkecil tingkat kecelakaan kerja, juga untuk pengembangan diri karyawan.

Adapun penelitian sebelumnya dilakukan oleh Lutfi (2018) dengan judul "Pengaruh Disiplin Kerja dan Motivasi Kerja terhadap Kinerja Karyawan (studi kasusu pada staff karyawan bagian produksi PT DOK dan Perkapalan Surabaya)" dari hasil penelitian ini dapat disimpulkan bahwa disiplin kerja dan motivasi kerja pengaruh positif terhadap kinerja karyawan.

Penelitian lain dilakukan oleh Tanujaya (2015) dengan judul "Pengaruh Pelatihan Kerja dan Motivasi Kerja terhadap Kinerja Karyawan Departemen Produksi PT Coronet Crown" dari hasil penelitian ini dapat disimpulkan bahwa pelatihan kerja dan motivasikerja memiliki pengaruh positif terhadap kinerja karyawan.

Dan penelitian yang dilakukan oleh Pratiwi \& Darmastuti (2014) dengan judul "Pengaruh Motivasi dan Disiplin Kerja terhadap Kinerja Karyawan pada PT Telekomunikasi Indonesia, Tbk Wilayah Telkom Pekalongan" dari hasil penelitian ini dapat disimpulkan bahwa variabel motivasi berpengaruh positif terhadap kinerja karyawan, sedangkan disiplin kerja tidak berpengaruh positif terhadap kinerja karyawan. 
Dari uraian latar belakang diatas penulis tertarik untuk melakukan penelitian dengan judul "PENGARUH DISIPLIN KERJA DAN PELATIHAN KERJA TERHADAP KINERJA KARYAWAN (Studi kasus PT.Ardena Artha Mulia bagian Produksi)"

\subsection{Perumusan Masalah}

1. Apakah disiplin kerja berpengaruh terhadap kinerja karyawan pada PT Ardena Artha Mulia bagian produksi?

2. Apakah pelatihan kerja berpengaruh terhadap kinerja karyawan pada PT Ardena Artha Mulia bagian produksi?

\subsection{Tujuan Penelitian}

1. Untuk mengetahui seberapa besar pengaruh disiplin kerja terhadap kinerja karyawan pada PT Ardena Artha Mulia bagian produksi.

2. Untuk mengetahui seberapa besar pengaruh pelatihan kerja terhadap kinerja karyawan pada PT Ardena Artha Mulia bagian produksi.

\subsection{Manfaat Penelitian}

Manfaat secara teoritis :

1. Memberikan kontribusi terhadap pengembangan ilmu manajemen sumber daya manusia yang berguna untuk bahan kajian atau informasi bagi pihak perusahaan maupun akademik.

2. Dapat digunakan sebagai referensi untuk penelitian mendatang melalui pengembangan model teoritikal dan model empiris yang belum diuji.

Manfaat secara praktis:

1. Bagi Perusahaan

Hasil peneliti ini diharapkan dapat dijadikan bahan masukan dan pertimbangan bagi perusahaan dalam menentukan langkah yang diambil terutama dalam bidang personalia yang berkaitan dengan disiplin kerja dan pelatihan kerja terhadap kinerja karyawan.

2. Bagi Peneliti

Sebagai tambahan wawasan serta belajar menganalisis suatu masalah yang berkaitan dengan disiplin kerja, pelatihan kerja dan kinerja karyawan.

\section{TINJAUAN PUSTAKA}

\subsection{Tinjauan Teoritis}

\section{Manajemen Sumber Daya Manusia}

Manajemen sumber daya manusia (human resource management) merupakan pendayagunaan sumber daya manusia untuk mencapai tujuan-tujuan organisasi (Ansory \& Indrasari, 2018).

Manajemen sumber daya manusia adalah suatu kegiatan pengelolaan yang meliputi pendayagunaan, pengembangan, penilaian, dan pemberian balas jasa bagi manusia sebagai individu suatu anggota organisasi atau perusahaan bisnis (Supomo dan Nurhayati, 2019).

Manajemen sumber daya manusia merupakan pengembangan dan pemanfaatan personel (pegawai) bagi pencapaian yang efektif mengenai sasaran-sasaran dan tujuan- 
tujuan individu, organisasi, masyarakat, nasional, dan internasional (Sudaryo dkk, 2018).

\section{Kinerja Karyawan}

Kinerja pada dasarkan adalah apa yang dilakukan atau tidak dilakukan oleh seorang pegawai dalam mengemban pekerjaannya (Priansa, 2019).

Kinerja merupakan hasil yang diproduksi oleh fungsi pekerjaan tertentu atau kegiatan pada pekerjaan tertentu selama periode waktu yang telah ditentukan (Priansa, 2017).

Kinerja adalah kontribusi yang dapat diberikan oleh suatu bagian, untuk sebuah pencapaian tujuan perusahaan (Kristansi dan Pangastuti, 2019).

\section{Disiplin Kerja}

Disiplin kerja adalah suatu alat yang digunakan para manager untuk berkomunikasi dengan karyawan agar mereka bersedia untuk mengubah suatu perilaku serta sebagai suatu upaya untuk meningkatkan kesadaran dan kesediaan seseorang menaati semua peraturan perusahaan dan norma-norma sosial yang berlaku di sekitarnya (Santoso, 2018).

Disiplin kerja adalah suatu sikap menghormati, menghargai, patuh, dan taat terhadap berbagai peraturan yang berlaku, baik yang tertulis maupun yang tidak tertulis, serta sanggup menjalankannya dan tidak mengelak untuk menerima sanksi apabila ada yang melanggar tugas serta wewenang yang diberikan kepadanya (Priansa, 2019).

Disiplin kerja adalah perilaku seseorang yang sesuai dengan peraturan, prosedur kerja yang ada, atau disiplin adalah sikap tingkah laku dan perbuatan yang sesuai dengan peraturan organisasi baik yang tertulis maupun yang tidak tertulis (Ramon, 2019).

\section{Pelatihan Kerja}

Pelatihan merupakan pembelajaran yang disediakan oleh perusahaan untuk meningkatkan kinerja karyawannya yang berkaitan dengan pekerjaan yang diberikan (Priansa, 2017).

Pelatihan merupakan upaya untuk bisa memperbaiki kinerja para tenaga kerja dalam bidang pekerjaannya. Para tenaga kerja harus bisa benar-benar melaksanakan tanggung jawabnya. Maka dari itu pelatihan sangat dibutuhkan sehingga keahlian bisa sangat menunjang untuk kinerja para pekerja (Riniwati, 2016).

Pelatihan adalah upaya yang sistematis dan terencana untuk mengubah atau mengembangkan pengetahuan atau keterampilan atau sikap melalui pengalaman belajar dalam rangka meningkatkan efektivitas berbagai kegiatan (Priansa, 2019). 


\subsection{Kerangka pemikiran}

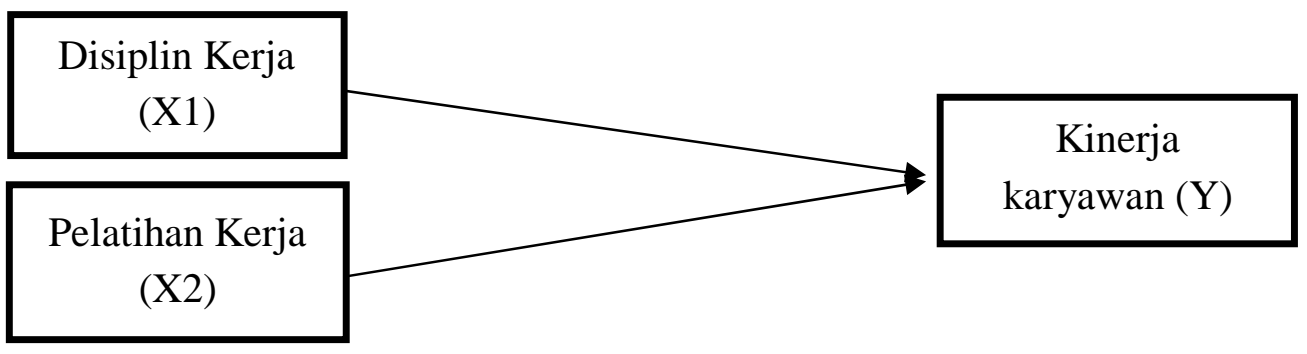

Gambar 2.1 Kerangka Pemikiran

Keterangka kerangka pemikiran diatas dapat dijelaskan bahwa :

$\mathrm{H} 1 \quad$ : Disiplin kerja $\left(\mathrm{X}_{1}\right)$, berpengaruh positif terhadap kinerja karyawan $(\mathrm{Y}) . \mathrm{H} 2$ : Pelatihan kerja $\left(\mathrm{X}_{2}\right)$, berpengaruh positif terhadap kinerja karyawan $(\mathrm{Y})$.

\section{METODE PENELITIAN \\ Populasi, Sampel dan Sampling}

Populasi dalam penelitian ini adalah karyawan tetap yang ada di PT Ardena Artha Mulia bagian produksi yang berjumlah 50 karyawan. Berdasarkan kondisi populasi yang berjumlah 50 orang, maka penelitian ini menggunakan nonprobability sample yaitu teknik pengambilan sampel yang tidak memberi peluang atau kesempatan sama bagi setiap unsur atau anggota populasi untuk dipilih menjadi sampel (sampling jenuh). Maka sampel yang diambil keseluruhan dari populasi tersebut yaitu sebanyak 50 responden.

\section{Metode Analisis Data}

Teknik analisis data yang digunakan dalam penelitian ini adalah uji validitas, Reliabilitas, pengujiaan asumsi klasik, analisis regresi sederhana, analisis korelasi sederhana, koefisien determinasi, uji F dan pengujian hipotesis. Alat pengelolaan data dalam penelitian ini adalah software IBM SPSS Statistics 25

\section{HASIL DAN PEMBAHASAN Karakteristik Responden}

Berdasarkan hasil penyebaran kuesioner kepada responden yang menjadi sampel dalam penelitian ini, maka adapun yang menjadi sampel adalah karyawan tetap yang ada di PT Ardena Artha Mulia bagian produksi. Maka berdasarkan jenis kelamin lakilaki sebanyak 34 orang dan wanita sebanyak 16 orang. Berdasarkan usia 19-24 tahun sebanyak 11 orang, 25- 30 tahun sebanyak 15 orang, 31-36 tahun sebanyak 19 orang, $>36$ tahun sebanyak 5 orang. 


\section{Uji Validitas dan Uji Reliabilitas}

Berdasarkan hasil uji validitas yang dilakukan dapat diperoleh bahwa semua instrument dalam penelitian ini valid yaitu nilai $r$ hitung lebih besar dari $r$ tabel sebesar 0,3610 . Sehingga semua instrument dapat digunakan dalam penelitian ini. Serta semua uji reliabilitas dapat diperoleh hasil bahwa semua instrument pernyataan dinyatakan reliable atau dapat dipercaya dan diandalkan karena nilai cronbach's alpha yang diperoleh melebihi 0,60 sehingga instrument layak untuk digunakan dalam penelitian ini.

\section{Uji Normalitas}

Uji normalitas digunakan untuk menguji apakah nilai residual terdistribusi normal atau tidak. Pengujian ini dilakukan dengan uji Probability Plot dan uji Komologrov Smirnov dengan nilai probabilitas signifikan $>0,05$ maka residual terdistribusi normal dan jika nilai probabilitas signifikansi $<0,05$ maka residual tidak terdistribusi normal. Adapun hasil pengujiannya sebagai berikut :

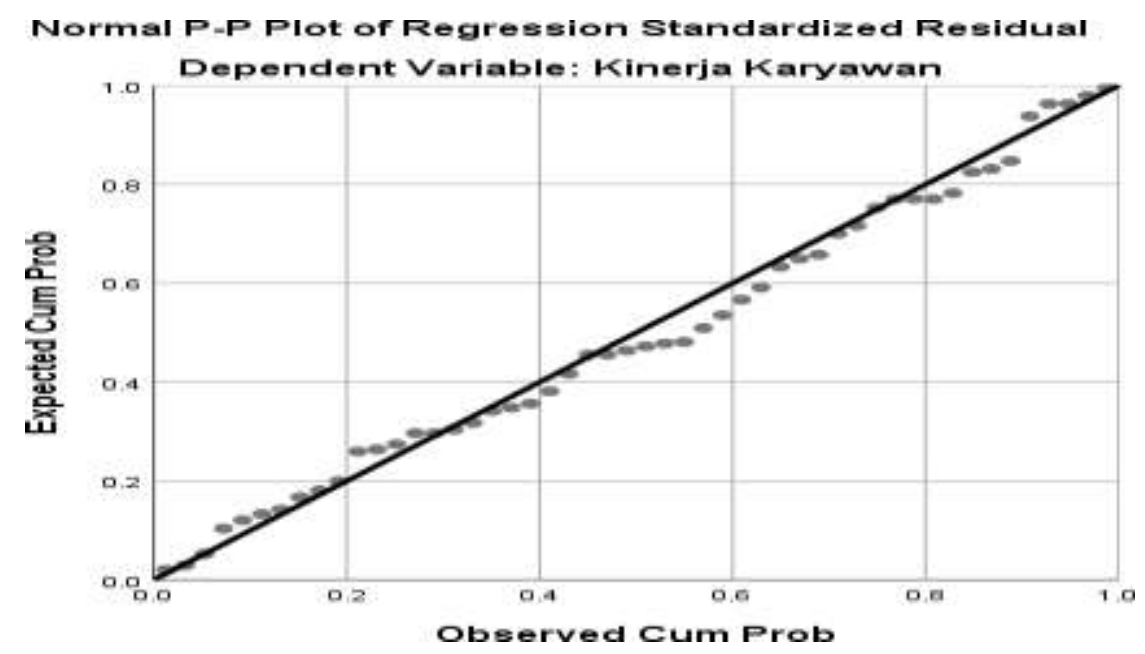

\section{Gambar 4.1}

Hasil Uji Normalitas Probability Plot

Sumber: hasil pengelolaan data SPSS 2020

Berdasarkan pada gambar 4.1 dapat dilihat bahwa titik-titik menyebar disekitar garis diagonal dan penyebarannya mengikuti arah garis diagonal, maka dapat dinyatakan data memenuhi asumsi normalitas.

Selanjutnya dilakukan uji normalitas dengan model Kolmogorov smirnv untuk mengetahui apakah data terdistribusi normal, maka dapat dilihat dalam tabel berikut : 
Tabel 441

Hasil Uji Normalitas Kolmogorov Smirnov

One-Sample Kolmogorov-Smirnov Test

\begin{tabular}{llr} 
& & $\begin{array}{c}\text { Unstandardized } \\
\text { Residual }\end{array}$ \\
\hline $\mathrm{N}$ & Mean & 50 \\
\cline { 2 - 3 } Normal Parameters ${ }^{\mathrm{a}, \mathrm{b}}$ & Std. Deviation & 3.18335026 \\
\hline Most Extreme Differences & Absolute & .079 \\
\cline { 2 - 3 } & Positive & .079 \\
\cline { 2 - 3 } & Negative & -.055 \\
\hline $\begin{array}{l}\text { Test Statistic } \\
\text { Asymp. Sig. (2-tailed) }\end{array}$ & .079 \\
\hline $\begin{array}{l}\text { a. Test distribution is Normal. } \\
\text { b. Calculated from data. } \\
\text { c. Lilliefors Significance Correction. } \\
\text { d. This is a lower bound of the true significance. } \\
\text { ber: Hasil pengolahan data SPSS } 2020\end{array}$ & $\mathbf{. 2 0 0}$ \\
\end{tabular}

Berdasarkan tabel 4.41 hasil uji normalitas dengan Kolmogorov smirnov dapat diketahui bahwa residual terdistribusi normal. Hal ini dapat dilihat dari nilai Asymp.Sig (2tailed) $>0,05$ yaitu $0,200>0,05$. Maka data terdistribusi normal.

\section{Uji Multikolinieritas}

Uji multikolinearitas bertujuan untuk menguji dalam model regresi ditemukan adanya korelasi antara variabel - variabel bebas (independen). Model regresi yang baik seharusnya tidak terjadi korelasi diantara variabel bebas (tidak terjadi multikoliniearitas). Alat statistik yang sering digunakan untuk menguji multikolinieritas dengan cara melihat nilai Variance Inflation Factor (VIF) masingmasing variabel independen, jika nilai toleransi masing- masing variabel bebas $>0,1$ dan VIF <10, maka dapat disimpulkan data bebas dari gejala multikolinieritas.. Adapun hasil pengujiannya sebagai berikut : 
Tabel 4.42

Hasil Uji Multikolinearitas

\section{Coefficients $^{\mathrm{a}}$}

\begin{tabular}{|c|c|c|c|c|c|c|c|}
\hline \multirow[b]{2}{*}{ Model } & \multicolumn{2}{|c|}{$\begin{array}{l}\text { Unstandardized } \\
\text { Coefficients }\end{array}$} & \multirow{2}{*}{$\begin{array}{c}\text { Standardized } \\
\text { Coefficients } \\
\text { Beta } \\
\end{array}$} & \multirow[b]{2}{*}{$\mathrm{t}$} & \multirow[b]{2}{*}{ Sig. } & \multicolumn{2}{|c|}{$\begin{array}{l}\text { Collinearity } \\
\text { Statistics }\end{array}$} \\
\hline & B & Std. Error & & & & Tolerance & VIF \\
\hline 1 (Constant) & 9.890 & 6.464 & & 1.530 & .133 & & \\
\hline Disiplin Kerja & .214 & .130 & .197 & 1.639 & .108 & .646 & 1.549 \\
\hline Pelatihan Kerja & .614 & .120 & .615 & 5.112 & .000 & .646 & 1.549 \\
\hline
\end{tabular}

a. Dependent Variable: Kinerja Karyawan

Sumber: Hasil pengolahan data SPSS 2020

Berdasakan tabel 4.42 terlihat bahwa nilai tolerance variabel disiplin kerja $\mathrm{X}_{1}$ $(0,646)$ dan pelatihan kerja $X_{2}(0,646)>0,1$ dan nilai $\operatorname{VIF}(1,549)<10$. Sehingga dapat disimpulkan bahwa tidak terjadi multikoliniearitas.

\section{Uji Heterokedastisitas}

Uji heteroskesdastisitas bertujuan untuk menguji apakah model dalam regresi terjadi ketidaksamaan varian dari satu pengamatan ke pengamatan yang lain. Adapun hasil pengujiannya sebagai berikut :

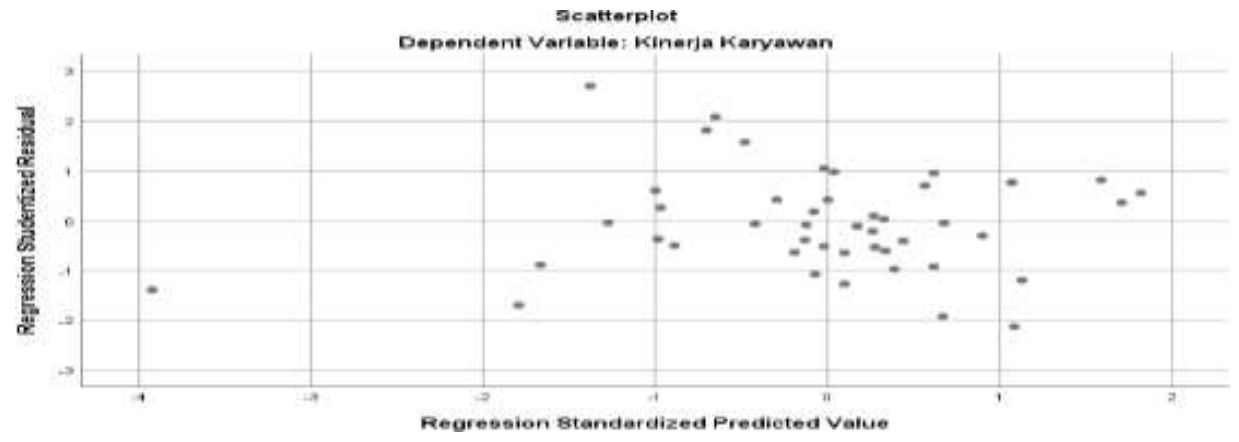

Gambar 4.2

Hasil Uji Heteroskedastisitas Scatterplot

Sumber: Hasil pengolahan data SPSS 2020

Berdasarkan gambar 4.2 scatterplot terlihat titik-titik menyebar dan tidak membentuk pola tertentu yang jelas. Sehingga dapat disimpulkan bahwa tidak terjadi heterokedastisitas. Uji heteroskedastisitas selanjutnya menggunakan metode glesjer dengan SPSS, heteroskedastisitas merupakan salah satu faktor yang menyebabkan model regresi linier tidak efisien dan akurat, model regresi yang baik ditandai dengan ttidak terjadi gejala heteroskesdastisitas. Jika nilai signifikansi (Sig) masing-masing variabel bebas $>0,05$ maka dapat disimpulkan data bebas dari gejala heterokedastisitas 
Tabel 4.43

Hasil Uji Heteroskedastisitas Glejser

Coefficients $^{\mathrm{a}}$

\begin{tabular}{|c|c|c|c|c|c|c|}
\hline \multicolumn{7}{|c|}{ Coemcients } \\
\hline & & \multicolumn{2}{|c|}{ Unstandardized Coefficients } & \multirow{2}{*}{$\begin{array}{c}\text { Standardized } \\
\text { Coefficients } \\
\text { Beta }\end{array}$} & \multirow[b]{2}{*}{$\mathrm{t}$} & \multirow[b]{2}{*}{ Sig. } \\
\hline & & $\mathrm{B}$ & Std. Error & & & \\
\hline \multirow[t]{3}{*}{$\overline{1}$} & (Constant) & 7.782 & 3.938 & & 1.976 & .054 \\
\hline & Disiplin Kerja & -.049 & .079 & -.109 & -.613 & .543 \\
\hline & Pelatihan Kerja & -.045 & .073 & -.109 & -.610 & .545 \\
\hline
\end{tabular}

a. Dependent Variable: Abs_Res

Sumber: hasil pengolahan data SPSS 2020

Berdasarkan tabel 4.43 dapat diketahui nilai signifikasi disiplin kerja $\mathrm{X}_{1}(0,543)$ dan pelatihan kerja $\mathrm{X}_{2}(0,545)>0,05$, maka dapat disimpulkan bahwa tidak terjadi gejala heteroskedastisitas pada model regresi diatas.

\section{Analisis Regresi Sederhana X1 \\ Terhadap Y:}

Tabel 4.44

Hasil Analisis Rgresi Sederhana $\mathrm{X}_{1}$ dan Y

Coefficients $^{\mathbf{a}}$

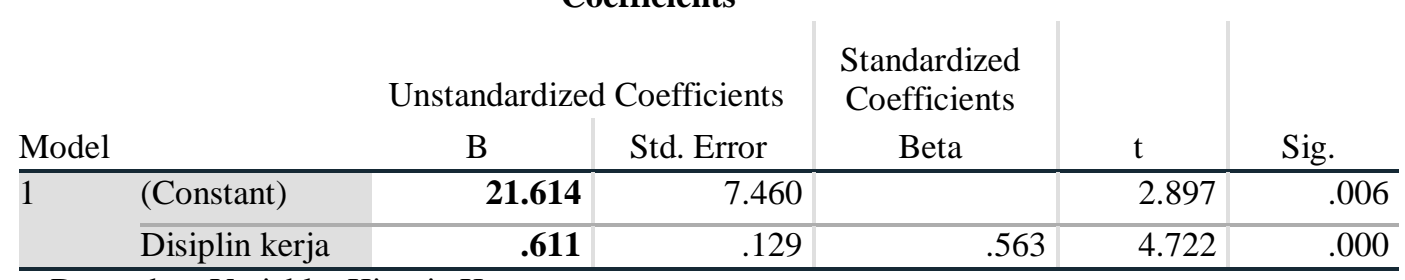

a. Dependent Variable: Kinerja Karyawan

Sumber : Hasil pengolahan data SPSS 2020

Dari persamaan diatas dapat diuraikan sebagai berikut:

Nilai a $=21,614$, artinya jika tidak ada perubahan dari variabel disiplin kerja, maka skor kinerja karyawan adalah 21,614.

Nilai $b=0,611$, artinya setiap penambahan satu skor atau nilai pada disiplin kerja, maka kinerja karyawan akan mengalami penambahan skor sebesar 0,611. 


\section{Analisis Regresi Sederhana X2 \\ Terhadap Y:}

Tabel 4.45

Hasil Analisis Regresi Sederhana $\mathbf{X}_{2}$ dan Y

Coefficients $^{\text {a }}$

\begin{tabular}{|c|c|c|c|c|c|c|}
\hline \multirow[b]{3}{*}{ Model } & \multicolumn{5}{|c|}{ Coefficients $^{\mathrm{a}}$} & \multirow[b]{3}{*}{ Sig. } \\
\hline & & \multicolumn{2}{|c|}{ Unstandardized Coefficients } & $\begin{array}{l}\text { Standardized } \\
\text { Coefficients }\end{array}$ & & \\
\hline & & $\mathrm{B}$ & Std. Error & Beta & $\mathrm{t}$ & \\
\hline 1 & (Constant) & 15.588 & 5.545 & & 2.811 & .007 \\
\hline & Pelatihan Kerja & .732 & .098 & .732 & 7.448 & .000 \\
\hline
\end{tabular}

a. Dependent Variable: Kinerja Karyawan

Sumber : Hasil pengolahan data SPSS 2020

Dari persamaan diatas dapat diuraikan sebagai berikut:

Nilai $\mathrm{a}=15,588$, artinya jika tidak ada perubahan dari variabel pelatihan kerja, maka skor kinerja karyawan adalah 15,588.

Nilai $b=0,732$, artinya setiap penambahan satu skor atau nilai pada pelatihan kerja maka kinerja karyawan akan mengalami penambahan skor sebesar 0,732

\section{Analisis Korelasi Sederhana dan Koefisien Determinasi Antara X1 Terhadap Y \\ Tabel 4.46 \\ Hasil Analisis Korelasi Sederhana dan Koefisien Determinasi X $\mathbf{1}_{1}$ dan Y Model Summary}

\begin{tabular}{ll|r|r|r} 
& & & \\
Model & $\mathrm{R}$ & R Square & Adjusted R Square & Std. Error of the Estimate \\
\hline 1 & $\mathbf{. 5 6 3}$ & .317 & .303 & 4.012 \\
\hline a. Predictors: (Constant), Disiplin Kerja & & \\
Sumber : Hasil pengolahan SPSS 2020 &
\end{tabular}

Berdasarkan tabel 4.46 dapat diketahui bahwa korelasi (R) antara disiplin kerja $\left(\mathrm{X}_{1}\right)$ terhadap kinerja karyawan $(\mathrm{Y})$ sebesar 0,563. Hal ini dapat diartikan bahwa terdapat hubungan yang "sedang" dan positif terhadap antara variabel disiplin kerja $\left(\mathrm{X}_{1}\right)$ terhadap variabel kinerja karyawan $(\mathrm{Y})$. Sedangkan nilai R Square sebesar 0,317 yang artinya disiplin kerja $\left(\mathrm{X}_{1}\right)$ memberikan kontribusi terhadap kinerja karyawan $(\mathrm{Y})$ sebesar $31,7 \%$ sedangkan sisanya 68,3\% dipengaruhi oleh faktor lain seperti : kompensasi, motivasi, gaya kepemimpinan, dan lain-lain.

\section{Analisis Korelasi Sederhana Dan Koefisien Determinasi Antara X2 Terhadap Y \\ Tabel 4.47 \\ Hasil Analisa Korelasi Sederhana dan Koefisien Determinasi $X_{2}$ dan Y Model Summary}

\begin{tabular}{ll|r|r|r} 
& & & \\
Model & $\mathrm{R}$ & R Square & Adjusted R Square & Std. Error of the Estimate \\
\hline 1 & $\mathbf{. 7 3 2}^{\mathrm{a}}$ & $\mathbf{. 5 3 6}$ & .526 & 3.307 \\
\hline
\end{tabular}

a. Predictors: (Constant), Pelatihan Kerja

Sumber : Hasil pengolahan SPSS 2020 
Berdasarkan tabel 4.47 dapat diketahui bahwa korelasi (R) antara pelatihan kerja $\left(\mathrm{X}_{2}\right)$ terhadap kinerja karyawan $(\mathrm{Y})$ sebesar 0,732 . Hal ini dapat diartikan bahwa terdapat hubungan yang "kuat" dan positif terhadap antara variabel pelatihan kerja $\left(\mathrm{X}_{2}\right)$ terhadap variabel kinerja karyawan (Y). Sedangkan nilai R Square sebesar 0,536 yang artinya pelatihan kerja $\left(\mathrm{X}_{2}\right)$ memberikan kontribusi terhadap kinerja karyawan $(\mathrm{Y})$ sebesar 53,6 \% sedangkan sisanya 46,4\% dipengaruhi oleh faktor lain seperti : lingkungan kerja, job description, pendidikan, dan lain-lain.

\section{Uji F}

\section{Tabel 4.48 Hasil Uji F ANOVA ${ }^{\mathrm{a}}$}

\begin{tabular}{|c|c|c|c|c|c|c|}
\hline & & $\begin{array}{l}\text { Sum of } \\
\text { Squares }\end{array}$ & Df & Mean Square & $\mathrm{F}$ & Sig. \\
\hline \multirow[t]{3}{*}{1} & Regression & 635.068 & 2 & 317.534 & 30.055 & $.000^{b}$ \\
\hline & Residual & 496.552 & 47 & 10.565 & & \\
\hline & Total & 1131.620 & 49 & & & \\
\hline
\end{tabular}

Diketahui bahwa $F_{h i t u n g}$ untuk variabel disiplin kerja $\left(\mathrm{X}_{1}\right)$ dan variabel pelatihan kerja $\left(X_{2}\right)$ sebesar 30,055 dan nilai signifikansi 0,000. Nilai $F_{h i t u n g}(30,055)>F_{\text {tabel }}(3,19)$ maka $\mathrm{H}_{\mathrm{a}}$ diterima $\mathrm{H}_{0}$ ditolak. Dan nilai signifikansi $(0,000<0,05)$ maka $\mathrm{H}_{\mathrm{a}}$ diterima $\mathrm{H}_{0}$ ditolak. Maka dapat disimpulkan bahwa disiplin kerja dan pelatihan kerja secara bersama-sama berpengaruh positif dan signifikan terhadap kinerja karyawan PT Ardena Artha Mulia.

\section{Uji T (Parsial)}

Tabel 4.49 Hasil Uji t Coefficients ${ }^{a}$

\begin{tabular}{|c|c|c|c|c|c|}
\hline \multirow[b]{2}{*}{ Model } & \multicolumn{2}{|c|}{$\begin{array}{l}\text { Unstandardized } \\
\text { Coefficients }\end{array}$} & \multirow{2}{*}{$\begin{array}{c}\text { Standardized } \\
\text { Coefficients } \\
\text { Beta }\end{array}$} & \multirow[b]{2}{*}{$\mathrm{t}$} & \multirow[b]{2}{*}{ Sig. } \\
\hline & $\mathrm{B}$ & Std. Error & & & \\
\hline 1 (Constant) & 9.890 & 6.464 & & 1.530 & .133 \\
\hline Disiplin Kerja & .214 & .130 & .197 & 1.639 & .108 \\
\hline Pelatihan Kerja & .614 & .120 & .615 & 5.112 & .000 \\
\hline
\end{tabular}

\section{Disiplin Kerja}

Diketahui bahwa nilai thitung untuk variabel disiplin kerja $\left(\mathrm{X}_{1}\right)$ 1,639 dan nilai signifikansi 0,108. Nilai thitung $(1,639)<\mathrm{t}_{\text {tabel }}(1,678)$ maka $\mathrm{H}_{\mathrm{a}}$ ditolak, $\mathrm{H}_{0}$ diterima. Dan nilai signifikansi $(0,108>0,05)$ maka $\mathrm{H}_{\mathrm{a}}$ ditolak, $\mathrm{H}_{0}$ diterima. Dapat disimpulkan bahwa secara parsial tidak terdapat pengaruh antara variabel disiplin kerja $\left(\mathrm{X}_{1}\right)$ terhadap kinerja karyawan (Y) PT. Ardena Artha Mulia bagian produksi. 


\section{Pelatihan Kerja}

Diketahui bahwa nilai $t_{\text {hitung }}$ untuk variabel pelatihan kerja $\left(X_{2}\right)$ 5,112 dan nilai signifikansi 0,000. Nilai $t_{\text {hitung }}(5,112)>\mathrm{t}_{\text {tabel }}(1,678)$ maka $_{\mathrm{a}}$ diterima, $\mathrm{H}_{0}$ ditolak. Dan nilai signifikansi $(0,000<0,05)$ maka $\mathrm{H}_{\mathrm{a}}$ diterima, $\mathrm{H}_{0}$ ditolak. Dapat disimpulkan bahwa secara parsial terdapat pengaruh positif dan signifikan antara variabel pelatihan kerja $\left(\mathrm{X}_{2}\right)$ terhadap kinerja karyawan (Y) PT. Ardena Artha Mulia bagian produksi.

\section{PEMBAHASAN}

Adapun berikut adalah hasil penelitian yang telah dilakukan oleh penulis, antara lain ialah: 1. Pengaruh disiplin kerja terhadap kinerja karyawan; 2. Pengaruh Pelatihan kerja terhadap kinerja karyawan.

\section{Pengaruh Disiplin Kerja terhadap Kinerja Karyawan}

Berdasarkan analisis data dapat diketahui bahwa variabel disiplin kerja tidak berpengaruh terhadap kinerja karyawan pada PT Ardena Artha Mulia bagian produksi.

Berdasarkan tanggapan responden dikaitkan dengan latar belakang dalam penelitian ini, bahwa dalam bekerja tiap karyawan dengan karyawan yang lainnya harus selalu saling menghormati, sehingga karyawan akan merasa nyaman dalam bekerja, dan juga semangat dalam menyelesaikan pekerjaan-pekerjaannya. Hal tersebut terbukti bahwa dengan menjalin sikap saling menghormati antar sesama karyawan dapat meningkatkan kinerja karyawan.

Akan tetapi berdasarkan fenomena yang ada di latar belakang bahwa masih banyak karyawan yang tidak masuk bekerja dan alasan terbesarnya karena alfa/ tidak hadir tanpa keterangan. Dengan begitu dapat dimungkinkan bahwa karyawan sering melakukan alfa atau tidak hadir tanpa keterangan dengan alasan kondisi lingkungan kerja sesama karyawannya kurang baik sehingga menimbulkan banyak karyawan malas masuk bekerja dan menurunkan kinerja dari karyawan tersebut. Jika hubungan sesama karyawan pada perusahaan terjalin baik, dapat dipastikan kedisiplinan karyawannya pun ikut lebih baik. Karena dengan menjaga kedisiplinan didalam perusahaan akan berdampak positif kepada perusahaan.

Setiap perusahaan memiliki peraturan-peraturan yang diterapkan berbeda-beda. Pada PT Ardena Artha Mulia menerapkan sanksi apabila jika karyawan yang bekerja khususnya bagian produksi melakukan alfa selama 15 kali dalam satu tahun akan diberhentikan kerja. Hal ini dilakukan agar karyawan dapat patuh terhadap peraturanperaturan yang ada demi kelangsungan dan kemajuan perusahaan.

Pendapat diatas dapat diperkuat dengan adanya teori menurut (Prawatya \& Raharjo, 2012) bahwa disiplin kerja pada dasarnya selalu diharapkan menjadi ciri setiap SDM dalam organisasi, karena dengan kedisiplinan organisasi akan berjalan dengan baik dan bisa mencapai tujuannya dengan baik pula.

Selain itu penelitian ini mempunyai hasil yang sama dengan penelitian sebelumnya yang dilakukan oleh Pratiwi \& Darmastuti (2014) yang berjudul "Pengaruh Motivasi dan Disiplin Kerja terhadap Kinerja Karyawan (studi kasus pada karyawan PT Telekomunikasi Indonesia, Tbk Wilayah Telkom Pekalongan", disiplin kerja secara parsial tidak berpengaruh terhadap kinerja karyawan. Berdasarkan hasil penelitian dilapangan menunjukkan bahwa disiplin kerja tidak berpengaruh terhadap kinerja karyawan PT Ardena Artha Mulia bagian produksi. 
2. Pengaruh Disiplin Kerja terhadap Kinerja Karyawan.

Berdasarkan analisis data dapat diketahui bahwa variabel pelatihan kerja berpengaruh positif dan signifikan terhadap kinerja karyawan pada PT Ardena Artha Mulia bagian produksi. Pernyataan tersebut dapat diartikan bahwa apabila pelatihan kerja ditingkatkan maka kinerja karyawan akan naik atau dapat meningkat demikian juga sebaliknya, apabila pelatihan kerja tidak ditingkatkan maka kinerja karyawan akan turun.

Berdasarkan tanggapan responden dikaitkan dengan latar belakang dalam penelitian ini dapat dilihat dari pernyataan yang diajukan dalam kuesioner, sebagian besar karyawan menjawab setuju pada pernyataan kuesioner yang diberikan. Karyawan mengikuti pelatihan untuk meningkatkan kinerja, pengetahuan, dan skill dalam bekerja. Hal ini memang menjadi tujuan perusahaan dalam mengadakan pelatihan kerja. Selain perusahaan menginginkan keuntungan yang besar, perusahaan juga menginginkan sumber daya manusia didalamnya dalam bekerja memiliki kualitas yang baik.

Hal lain berdasarkan tanggapan responden dikaitkan dengan latar belakang dalam penelitian ini yang dapat dilihat dari pernyataan yang diajukan dalam kuesioner, sebagian karyawan mengatakan setuju dengan fasilitas ruagan yang dipakai untuk pelatihan luas, bersih dan terawat. Jika fasilitas berupa ruangan ini mendukung, maka pelaksanaan pelatihan kerjapun akan terasa lebih nyaman. Peserta pelatihan akan mudah fokus dalam menerima materi-materi yang diberikan. Dan tujuan dari pelatihan itu sendiri akan lebih mudah tercapai.

Sumber daya manusia adalah salah satu aset terpenting didalam perusahaan. Dengan karyawan mengikuti pelatihan-pelatihan yang ada, dimungkinkan akan berpengaruh besar bagi hasil yang didapat perusahaan. Perusahaan jadi memiliki karyawan-karyawan yang berkualitas, memiliki tingkat ketelitian yang tinggi, dapat mengefisienkan waktu bekerja dengan sebaik mungkin, dan sebagai pengembangan diri karyawan tersebut.

Pendapat diatas dapat diperkuat dengan adanya teori menurut Bangun (2012:203) menyatakan bahwa pelatihan merupakan suatu proses untuk memperbaiki keterampilan kerja karyawan untuk membantu pencapaian tujuan perusahaan.

Penelitian ini mempunyai hasil yang sama dengan penelitian sebelumnya yang dilakukan oleh Tanujaya (2015) yang berjudul "Pengaruh Pelatihan Kerja dan Motivasi Kerja terhadap Kinerja Karyawan Departemen Produksi PT Coronet Crown", pelatihan kerja secara parsial berpengaruh positif dan signifikan terhadap kinerja karyawan. Berdasarkan hasil penelitian dilapangan menunjukkan bahwa pelatihan kerja berpengaruh positif dan signifikan terhadap kinerja karyawan PT Ardena Artha Mulia bagian produksi.

\section{KESIMPULAN}

Berdasarkan hasil penelitian yang telah dilakukan mengenai pengaruh Disiplin Kerja dan Pelatihan Kerja terhadap Kinerja Karyawan pada PT Ardena Artha Mulia bagian Produksi, maka dapat diperoleh simpulan sebagai berikut :

1) Berdasarkan hasil penelitian yang dilakukan, diperoleh bahwa Disiplin Kerja tidak berpengaruh terhadap Kinerja Karyawan, dilihat dari hasil Uji T antara variabel $\mathrm{X} 1$ 
2) Berdasarkan hasil penelitian yang dilakukan, diperoleh bahwa Pelatihan Kerja memiliki pengaruh terhadap Kinerja Karyawan, dilihat dari hasil Uji T antara variabel X2 dengan Y, hasil data menunjukkan bahwa Disiplin Kerja memiliki pengaruh yang positif dan signifikan terhadap Kinerja Karyawan.

\section{Saran}

Saran yang dapat disampaikan penulis berdasarkan penelitian dan berdasarkan hasil

jawaban responden terhadap kuesioner mengenai Kompensasi (X1) dan Disiplin Kerja (X2) dan Kinerja Karyawan (Y) adalah sebagai berikut:

1. Sebaiknya perusahaan dapat berlaku adil kepada seluruh karyawan tanpa membeda- bedakan jabatan, lamanya bekerja, gender, dan lain lain. Apabila mengadakan pelatihan kerja perusahaan sebaiknya memilih pelatih/instruktur untuk menyampaikan materi kepada peserta harus yang memiliki keahlian terlebih dahulu dibidangnya, agar pengajaran yang diberikan lebih efektif. Dan juga diharapkan materi yang diberikan untuk peserta pelatihan sudah dipersiapkan dengan matang-matang dan juga lengkap agar pada saat pelatihan dimulai peserta mendapatkan materi-materi yang lengkap untuk menunjang segala pekerjaannya pada PT Ardena Artha Mulia. Dan sebaiknya untuk seluruh karyawan dapat berkompetisi dalam menjalankan pekerjaanpekerjannya dengan kualitas yang paling baik untuk memicu kualitas kinerja karyawan menjadi lebih baik.

2. Diharapkan agar penelitian selanjutnya dapat mengembangkan hasil dalam penelitian ini dengan menambah jumlah sampel atau variabel lainnya yang dapat mempengaruhi kinerja karyawan. Serta untuk teknik analisisnya dapat menggunakan metode seperti ini ataupun metode lain seperti metode kualitatif agar didapatkan hasil yang lebih luas. 


\section{DAFTAR PUSTAKA}

Al-Qur'an

Andayani, N. R., \& Makian, P. 2016. Pengaruh Pelatihan Kerja dan Motivasi Kerja Terhadap kinerja Karyawan Bagian PT. PCI Elektronik International (Studi pada Karyawan PT. PCI Elektronik Internasional). Jurnal Akuntansi, Ekonomi Dan Manajemen Bisnis. 4(1): 41-46.

Ansory, A., \& Indrasari, M. 2018. Manajemen Sumber Daya Manusia. Edisi 1, Indonesia Pustaka.Sidoarjo.

Astuti, S. F. 2018. Analisis Pengaruh Promosi Jabatan, Disiplin Kerja dan Motivasi Spiritual Terhadap Kinerja Karyawan Pada Bank Tabungan Negara ( BTN ) Syariah Kantor Cabang Semarang. Ekonomi. 1(1): 1-91.

Bangun, W. 2012. Manajemen Sumber

Daya Manusia. Edisi 1, Erlangga. Jakarta. Burhannudin, dkk. 2019. Pengaruh Disiplin Kerja, Lingkungan Kerja, dan Komitmen

Organisasional terhadap Kinerja Karyawan: Studi pada Rumah Sakit Islam

Banjarmasin. Jurnal Maksipreneur: Manajemen, Koperasi, Dan Entrepreneurship. 8(2): 191-206.

Gunawan, A. A., \& Sunardi, H. 2016. Pengaruh Kompensasi Dan Disiplin Kerja Terhadap Kinerja Karyawan Pada PT Gesit Nusa Tangguh. Jurnal Ilmiah Manajemen Bisnis. 16(1): 3.

Hadifa, L. 2019. Membangun Budaya Anti Korupsi di Lingkungan Organisasi Pemerintah daerah. Edisi 1, CV Adiprima Pustaka. Kendari.

Hermawan, I. 2019. Metodologi Penelitian Pendidikan Kuantitatif, Kualitatif Dan Mexed Methode. Edisi 1, Hidayatul Quran Kuningan. Jakarta.

Istiana, \& Manurung, A. D. R. 2018. Pengaruh Komitmen Organisasi, Disiplin Kerja, dan Kualitan Kehidupan Kerja terhadap Prestasi Kerja Karyawan Universitas Mercu Buana Jakarta. Jurnal SWOT. 8(2): 294.

Kristansi, D., \& Pangastuti, R. L. 2019. Kiat-Kiat Merangsang Kinerja Karyawan Bagian Produksi. Edisi 1, Media Sahabat Cendekia. Surabaya.

Leuhery, F. 2018. Pengaruh Kualitas Sumber Daya Manusia, Disiplin Kerja, dan Pengembangan Karir Terhadap Prestasi Kerja Pegawai Dinas Perhubungan Provinsi Maluku. Jurnal SOSOQ. 6(1): 118-133.

Lolowang, M. G., dkk . 2016. Pengaruh Pelatihan dan Pengembangan Sumber Daya Manusia terhadap Kinerja Karyawan pada OT Berlian Kharisma Pasifik Manado. EMBA. 4(2): 177-186.

Lutfi, A. F. 2018. Pengaruh Disiplin Kerja Dan Motivasi Kerja Terhadap Kinerja Karyawan (Studi Kasus Staff Karyawan Bagian Produksi PT. Dok Dan Perkapalan Surabaya). Jurnal Ilmu Manajemen (JIM). 6(3): 51-57.

Mamik. 2016. Manajemen Sumber Daya

Manusia. Edisi 1, Zifatama Jawara. Sidoarjo. Pratiwi, A., \& Darmastuti, I. 2014. Pengaruh Motivasi dan Disiplin Kerja Terhadap Kinerja

Pegawai (Studi Pada PT. Telekomunikasi Indonesia, Tbk Wilayah Telkom Pekalongan).

Diponegoro Journal of Management. 2(1): 1-13.

Prawatya, D. A., \& Raharjo, S. T. 2012. Terhadap Kinerja Karyawan Pabrik Minyak Kayu Putih ( PMKP ) Di Krai Purwodadi. Diponegoro Journal of Management. 1(1): 1-9. 
Priansa, D. J. 2017. Manajemen Kinerja

Kepegawaian. Edisi 1, CV Pustaka Setia. Bandung. Priansa, D. J. 2019. Pengembangan dan Pelatihan Sdm Perusahaan. Edisi 1, Simbiosa

Rekatama Media. Bandung.

Ramon, Z. 2019. Lingkungan Kerja, Disiplin Dan Stres Kerja Pada PT Escotama Handal Batam. 7(2): 48-55.

Riniwati, H. 2016. Manajemen Sumber

Daya Manusia. Edisi 1, UB Press. Malang. Rozalia, N. A., dkk. 2015. Pengaruh

Motivasi Kerja dan Disiplin Kerja terhadap Kinerja

Karyawan (Studi Kasus Pada Karyawan PT . Pattindo Malang). Jurnal Administrasi Bisnis. 26(2): 1-8.

Santoso, A. B. 2018. Pengaruh Disiplin Kerja, Motivasi, Dan Komitmen Organisasi

Terhadap Kinerja Karyawan (Pada PT. Bank Negara Indonesia (Persero) Cabang Pamulang). Jurnal Mandiri. 1(2): 248-271.

Sihombing, S., dkk. 2015. Manajemen

Sumber Daya Manusia. Edisi 1, In Media. Jakarta. Sinabela, L. P. 2018.

Manajemen Sumber Daya Manusia. Edisi 3, PT Bumi Aksara. Jakarta. Sisca,

dkk. 2020. Teori-Teori Manajemen Sumber Daya Manusia. Edisi 1, Yayasan Kita Menulis. Indonesia.

Sudaryo, Y., dkk. 2018. Manajemen Sumber Daya Manusia, Kompensasi Tidak

Langsung dan Langsung Kerja Fisik. Edisi 1 Andi. Yogyakarta.

Sugiarto. 2017. Metodologi Penelitian Bisnis. Edisi 1, Andi. Yogyakarta.

Sujarweni, V. W. 2019. Metodologi Penelitian. Edisi 1, Pustaka Baru Press.

Yogyakarta.

Suparyadi, H. 2015. Manajemen Sumber

Daya Manusia, Edisi 1, CV Andi Offset.Yogyakarta.

Supomo, R., \& Nurhayati, E. 2019. Manajemen Sumber Daya Manusia. Edisi 2, Yrama Widya. Bandung.

Syahyuni, D. 2018. Hubungan Antara Kinerja Karyawan Dengan Promosi Jabatan Pada Unit Taman Marga

Satwa Ragunan Dinas Kehutanan Provinsi DKI Jakarta. Widya Cipta. 2(1): 76-82.

Tanujaya, L. R. 2015. Pengaruh Pelatihan dan Motivasi Kerja pada Kinerja Karyawan Departemen Prosuksi PT Coronet Crown. Journal of Management Development. 3(1): 1-7.

Umar, H. 2019. Metode Riset Manajemen Perudahaan. Edisi 1, PT Gramedia Pustaka Utama. Jakarta.

Zulfikar. 2016. Pengantar Pasar Modal dengan Pendekatan Statistika. Edisi 1, CV

Budi Utama. Yogyakarta. 